\title{
Measuring Level of Information and Communication Technology Literacy of University Students in Indonesia
}

\author{
Yonathan Anggian Siahaan \\ Information Systems Management Department \\ Bina Nusantara University \\ Jakarta, Indonesia \\ yonathananggiansiahaan@gmail.com
}

\author{
Fergyanto E Gunawan \\ Industrial Engineering Department \\ Bina Nusantara University \\ Jakarta, Indonesia \\ fgunawan@binus.edu
}

\begin{abstract}
Nowadays, Information and Communication Technology (ICT) competency, well known as ICT literacy, is an essential prerequisite for modern professionals. The purpose of this study is to measure the level of ICT literacy of university students. The first section in your paper. The study adopts the People Capability Maturity Model (P-CMM) framework to measure the ICT literacy level and Digital Competency (DIGCOMP) to identify the factors. The data are collected using online questionnaires from a random sample of 400 students in Indonesia. The level of literacy is just a weighted average of the participants' responses. The results suggest that the level of ICT literacy of Indonesian university students is in level three, indicating that on average, the students understand and can apply ICT consistently to achieve their objectives.
\end{abstract}

Keywords: Information and Communication Technology, Literacy, People Capability Maturity Model, Digital Competency

\section{INTRODUCTION}

Information and communication technology (ICT) skills known as 'ICT Literacy' is an important prerequisite for success for professionals [1] and students [2] which is a phase before heading into being professional. Students with low ICT skills often get low academic grades and small opportunities to get a job [3]. In their study, [4] found $81 \%$ of students used the Internet to get information related to academic tasks. Nowadays, well-known information society where describes the conditions of people who use ICT to fulfil their welfare [5]. With the improvement of ICTs today, the internet is an important tool. In a study, it was found that the use of efficient information search with the Internet had a positive effect [6]. This study identifies the level of ICT competence among students in Indonesia measurements were carried out quantitatively using the self-reported questionnaire. The results obtained can be useful as a reference for the world of education in Indonesia in utilizing ICT as one of the supporting success of students.

\section{LITERATURE REVIEW}

The International Computer and Information Literacy Study (ICILS) identify a framework concept in two streams. The first stream is "collecting and managing information", focusing on the elements of acceptance and organization of information processing and management [7]. There are three aspects inside: knowing about computers and their uses, accessing and evaluating information (the process by which someone searches, receives and makes decisions about the integrity, relevance, and usefulness of computer-based information) and manage information (the capacity of individuals to adapt and adjust classification schemes and organizations to organize and store information efficiently). The second stream is "making and exchanging information", focusing on the use of computers as a means of thinking, creating and communicating. There are four aspects inside: changing information (the use of computers to change how information is represented and can be understood by the recipient of information), making information (the use of computers to design and produce information products for the purpose and recipient of certain information), sharing information (use computer to communicate and exchange information with others), use information carefully and safely (understand the law and ethics in computer-based communication).

In his research, Ivankovic [4] defined ICT skills as an ability to use information technology and communication tools that are described in the ability to access the Internet, and organize, integrate, evaluate, and produce functional information. UNESCO, a PBB agency, grouping ICT capabilities into three, namely: (a) the competence of digital literacy related to the use of ICT for presentations in the classroom and the involvement of digital tools in obtaining information; (b) implementation competencies namely skills and knowledge to work on complex projects or tasks, solving with simulations of a problem in the real world; and (c) ethical competence related to the use of ICT legally and responsibly [8].

In the current era of an information society, a lot of information is disseminated through various media, and this information can be used by people to find out the actual conditions around it as well as to be a solution for the needs [9]. Computer literacy is the ability to use a computer to meet personal needs. Son, Robb, and Charismiadji [10] define computer literacy in general as the ability to use computers at an adequate level for creation, communication, and collaboration in educated societies [11]. From an education perspective, it can be interpreted to be the development of knowledge and skills for general computer applications, software programs, and the internet competently. Digital literacy is utilizing information or technology with digital 
offerings in daily needs [12]. Digital literacy can be associated with several broader technologies. The focus of the emphasis is not only on computer operations and programming, both of which are important parts of ICT literacy [7]. Internet literacy is the ability to use theoretical knowledge and practical use the internet as a medium of communication and information [5]. The role of internet literacy is inseparable from computers, where the internet is a globalized system and connects computers in networks, applications in education, government, business, and various organizations.

\section{A. Measurement ICT Literacy}

There are many ways to measure ICT literacy. Many researchers make use of self-efficacy over one's ability regarding computers and the internet. Some other researchers chose to use achievement tests (actual ability tests) [13]. Measurement of ICT literacy using self-efficacy refers to individual beliefs that they can succeed in a particular task, derived from external experience and self-perception of the tasks and conditions they encounter [14]. Respondents are faced with a question and then measure themselves about their ability to process and utilize ICT through a survey. This is widely chosen by researchers because it is considered as an efficient, inexpensive and easy to do method. In this study involve 400 university students as random respondents to give feedback using online questionnaire. After all questionnaire collected, continue processing data to get the result.

Two frameworks will be adopted there is People Capability Maturity Model (P-CMM) to determine the level of ICT literacy level. ICT skills can be measured using the Personal Capability Maturity model abbreviated as P-CMM [15]. This model has five levels: level 1 (initial), level 2 (repeatable), level 3 (defined), level 4 (predictable), and level 5 (optimized). To categorize ICT literacy measurement use Digital Competency framework [16]. Refer to its website (https://ec.europa.eu/jrc/en/digcomp/digital-competenceframework) there are five category as a measurement test of competence: Internet Activity, Communication and Collaboration, Content Digital, Security and Problem Solving [17].

\section{RESULT}

There are 400 participants spread from 90 universities in Indonesia who take part in this survey by online questionnaire. About $63.5 \%$ students come from the engineering department and $36.5 \%$ from non engineering department with respondent's age variance from 18 to 34 years. The time taken to complete the questionnaire on average was 10 minutes. Some respondents required as long as 15 minutes.

After collecting the feedback we continue to processing and calculate the data we have. The result we have (see fig. 1), the level of ICT literacy university student in Indonesia between the range 3.2-3.7 and grouped into level 3 (Defined) category in the P-CMM. This shows that five areas competence of students in Indonesia already has sufficient standards in mastering ICT's and begin to understand the use of ICT's to meet the goals and needs of students. Internet activity becomes an area of competence that has the best average score.

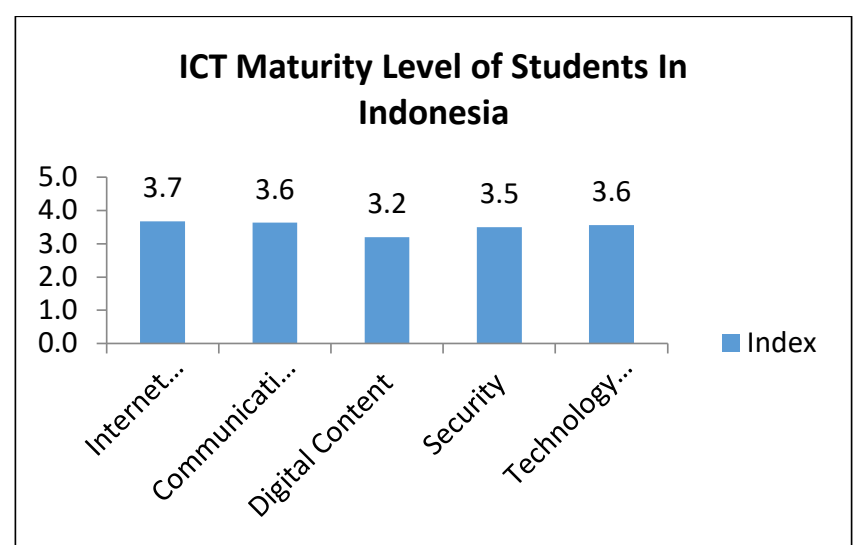

Figure 1. Maturity level ICT Literacy university students in Indonesia

This provides information that Indonesian students can adequately utilize the internet as a source of information. Statistic calculation (see appendices A1) shows details of measurement results test from each competence area of ICT Literacy collected from students' feedback. The data indicates 3 top ICT literacy there is active using email, IM, blog for their communication $($ Mean $=4.240 ; \mathrm{SD}=0.918)$, accustomed internet to looking for certain files using internet $($ Mean $=$ 3.957; SD = 1.045), and utilize technology digital for problem solving (Mean $=3.937$; SD = 1.049). It also ICT literacy which have lower score such change/modify web using programming language $($ Mean $=2.795 ; \mathrm{SD}=1.261)$ and utilize Google voice or Siri to find place $($ Mean $=2.867$; SD $=1.150)$.

\section{DISCUSSION}

This research has given evaluation about how the maturity level ICT literacy students in Indonesia. Research question answered with the result students in Indonesia has ICT literacy level 3 (defined) which indicate students is enough knowledge and try to utilize ICT enriching their activity. The lowest score get from Digital Content competency area, so it needs serious attention from our government to focus on triggering the government focuses on addressing learning about digital content knowledge among students from an early age [12], [18]. It will have a huge impact due to now it a requirement for collaborative digital business capability nowadays [19].

\section{CONCLUSION}

This study measures level of information and communication technology literacy of university students in Indonesia. The results suggest that the level of ICT literacy of Indonesian university students is in level three, indicating that on average, the students understand and can apply ICT consistently to achieve their objectives. This competency assessment is highlighted to monitor and determine the development and status of ICT literacy, which are assessed from several aspects of the assessment perspective taken directly from university students in Indonesia. Nevertheless, this study still approaches the limited aspects of competency assessment, which is carried out from the respondent's selfefficacy. These calls for further research, which may deploy and using such frameworks to investigate factors influence the ICT literacy level. 


\section{REFERENCES}

[1] J. Zylka, G. Christoph, U. Kroehne, J. Hartig, and F. Goldhammer, "Moving beyond cognitive elements of ICT literacy: First evidence on the structure of ICT engagement," Comput. Human Behav., vol. 53, pp. 149-160, 2015.

[2] P. Slechtova, "Attitudes of Undergraduate Students to the Use of ICT in Education," Procedia - Soc. Behav. Sci., vol. 171, pp. 1128-1134, 2015.

[3] W. Techataweewan and U. Prasertsin, "Development of digital literacy indicators for Thai undergraduate students using mixed method research,” Kasetsart J. Soc. Sci., pp. 1-7, 2017.

[4] A. Ivanković, S. Špiranec, and D. Miljko, "ICT Literacy among the Students of the Faculty of Philosophy, University of Mostar," Procedia - Soc. Behav. Sci., vol. 93, pp. 684-688, 2013.

[5] B. Saleh, "Information and Communication Technology (ICT) Literacy of Community in Mamminasata Region," J. Pekommas, vol. 18, no. 3, pp. 151-160, 2015.

[6] L. Salmerón, A. García, and E. Vidal-Abarca, "The development of adolescents' comprehension-based Internet reading activities," Learn. Individ. Differ., vol. 61, no. November 2016, pp. 31-39, 2018.

[7] J. Ainley, W. Schulz, and J. Fraillon, "A global measure of digital and ICT literacy skills,” Glob. Educ. Monit. Report, Educ. people planet Creat. Sustain. Futur. all, 2016.

[8] C. A. T. Gastelú, G. Kiss, and A. L. Domínguez, "Level of ICT Competencies at the University," Procedia - Soc. Behav. Sci., vol. 174, pp. 137-142, 2015.

[9] A. Isazadeh, "Information society: concepts and definitions," WSEAS Trans. Syst., vol. 3, no. 6, pp. 2407-2410, 2004.

[10] J.-B. Son, T. Robb, and I. Charismiadji, "Computer literacy and competency: a survey of Indonesian teachers of English as a foreign language,” Comput. Lang. Learn. Electron. J., 2011.

[11] D. Tafazoli, E. Gó, and C. A. H. Abril, “Computer Literacy : Sine Qua Non for Digital Age of Language Learning \& Teaching," vol. 7, no. 9, pp. 716-722, 2017.

[12] A. Rahmah, "Digital Literacy Learning System for Indonesian Citizen," Procedia Comput. Sci., vol. 72, pp. 94-101, 2015.

[13] S. Oktafani, A. E. Permanasari, and E. Nugroho, "Model Konseptual Faktor-faktor yang Mempengaruhi Literasi Komputer Pegawai Pemerintah,” Semin. Nas. Teknol. Informasi, Komun. dan Apl., vol. 4, no. 2089-1083, 2017.

[14] A. G. Kolo, W. M. B. W. Jaafa, and N. B. Ahmad, "Relationship between Academic Self-efficacy Believed of College Students and Academic Performance.," IOSR J. Humanit. Soc. Sci., vol. 22, no. 01, pp. 75-80, 2017.

[15] C. Zhang, "Design of human capability maturity analysis system online P-CMM model," Proc. - 2015 Int. Conf. Intell. Transp. Big Data Smart City, ICITBS 2015, pp. 302-305, 2016.

[16] F. Siddiq, “Assessment of ICT Literacy," 2016.

[17] A. Ferrari, "DIGCOMP: A Framework for Developing and Understanding Digital Competence in Europe.," 2013.

[18] R. Owston, H. Wideman, N. S. Ronda, and C. Brown, "Computer game development as a literacy activity," Comput. Educ., 2009.

[19] O. González-Rojas, D. Correal, and M. Camargo, "ICT capabilities for supporting collaborative work on business processes within the digital content industry," Comput. Ind., 2016. 
Appendices

Table A1. Percentage distribution, mean and standard deviations measurements item relative to the ICT literacy level student in Indonesia

\begin{tabular}{|c|c|c|c|c|c|c|c|}
\hline Competency & 1 & 2 & 3 & 4 & 5 & Mean & SD \\
\hline \multicolumn{8}{|l|}{ Internet Activity } \\
\hline $\begin{array}{l}\text { Find and save certain files using search } \\
\text { engine }\end{array}$ & 3.25 & 6.75 & 17 & 37 & 36 & 3.9575 & 1.04567 \\
\hline Test credibility and validity information & 3 & 11.5 & 29.75 & 37 & 18.75 & 3.5700 & 1.01621 \\
\hline Using web feeds & 5.75 & 15.25 & 34.75 & 28.5 & 15.75 & 3.3325 & 1.09083 \\
\hline Classification files information or data & 3 & 6.75 & 23.25 & 36.25 & 30.75 & 3.8500 & 1.02964 \\
\hline Operate cloud facilites storing data & 3.5 & 12.75 & 22.25 & 36.75 & 24.75 & 3.6650 & 1.08892 \\
\hline \multicolumn{8}{|l|}{ Communication } \\
\hline Active using email, IM, blog, etc & 1.75 & 2.75 & 14.25 & 32.25 & 49 & 4.2400 & .91897 \\
\hline Create content collaboration online & 4.75 & 9.5 & 26.25 & 35.75 & 23.75 & 3.6425 & 1.08750 \\
\hline Design blog for sharing knowledge & 6.5 & 17.75 & 31 & 29.75 & 15 & 3.2900 & 1.11984 \\
\hline Operate cloud for sharing data & 4.25 & 13 & 27.75 & 35.5 & 19.5 & 3.5300 & 1.07564 \\
\hline $\begin{array}{l}\text { Using e-banking, e-ticketing, online } \\
\text { shopping }\end{array}$ & 3.25 & 10 & 19.5 & 36.25 & 31 & 3.8175 & 1.08033 \\
\hline Operate remote access desktop & 9.75 & 15.5 & 30.25 & 25.25 & 19.25 & 3.2875 & 1.22007 \\
\hline \multicolumn{8}{|l|}{ Digital Content } \\
\hline $\begin{array}{l}\text { Making ad design using photoshop, corel } \\
\text { draw, etc }\end{array}$ & 10 & 24.5 & 31.25 & 23 & 11.25 & 3.0100 & 1.15248 \\
\hline Create website or blog using template & 7 & 17 & 30.25 & 29.25 & 16.5 & 3.3125 & 1.14373 \\
\hline $\begin{array}{l}\text { Change/modify web design using } \\
\text { programming language }\end{array}$ & 19.5 & 21.75 & 29.5 & 18 & 11.25 & 2.7975 & 1.26114 \\
\hline Knowing use of copyright from information & 9.75 & 19 & 32 & 23.75 & 15.5 & 3.1625 & 1.18938 \\
\hline $\begin{array}{l}\text { Utilize text, audio, image and clips making } \\
\text { video }\end{array}$ & 5 & 14.25 & 31.25 & 29.5 & 20 & 3.4525 & 1.11168 \\
\hline $\begin{array}{l}\text { Utilize formula and macro for manage } \\
\text { database }\end{array}$ & 5.75 & 13.5 & 33 & 28.75 & 19 & 3.4175 & 1.11414 \\
\hline \multicolumn{8}{|l|}{ Security } \\
\hline $\begin{array}{lll}\begin{array}{l}\text { Preventive computer/smartphone from } \\
\text { virus }\end{array} & \\
\end{array}$ & 3.5 & 14.5 & 33.25 & 31.5 & 17.25 & 3.4450 & 1.04628 \\
\hline Scam/phising identification on e-mail & 6.25 & 14.25 & 31.5 & 29.25 & 18.75 & 3.4000 & 1.13057 \\
\hline $\begin{array}{l}\text { Creating password combination } \\
\text { letters, numbers, and symbol }\end{array}$ & 5.25 & 14 & 22 & 29.75 & 29 & 3.6325 & 1.18784 \\
\hline $\begin{array}{l}\text { Delete cookies, saved login and history } \\
\text { internet browser }\end{array}$ & 4.25 & 14.25 & 30.5 & 26.75 & 24.25 & 3.5250 & 1.13030 \\
\hline \multicolumn{8}{|l|}{ Problem Solving } \\
\hline $\begin{array}{lrlr}\begin{array}{l}\text { Aware and adapt of technology } \\
\text { developments }\end{array} & & & \\
\end{array}$ & 3.5 & 8.25 & 19.25 & 37 & 32 & 3.8575 & 1.06773 \\
\hline $\begin{array}{l}\text { Utilize digital technology for problem } \\
\text { solving }\end{array}$ & 2.5 & 8.5 & 17.75 & 35.25 & 36 & 3.9375 & 1.04945 \\
\hline Using Google voice or Siri to find place & 15 & 21 & 33.75 & 22.75 & 7.5 & 2.8675 & 1.15033 \\
\hline Upgrade digital competencies & 3 & 10.5 & 31 & 36.25 & 19.25 & 3.5825 & 1.01032 \\
\hline
\end{tabular}

